Article

\title{
Electrocatalytic water oxidation by a nickel oxide film derived from a molecular precursor
}

\author{
Fei Li a,*, Hua Li a, Yong Zhu a, Jian Du a, Yong Wang a, Licheng Sun a,b \\ a State Key Laboratory of Fine Chemicals, DUT-KTH Joint Education and Research Center on Molecular Devices, Dalian University of Technology (DUT), \\ Dalian 116024, Liaoning, China \\ b Department of Chemistry, School of Chemical Science and Engineering, KTH Royal Institute of Technology, Stockholm 10044, Sweden
}

\section{A R T I C L E I N F}

\section{Article history:}

Received 30 August 2017

Accepted 25 September 2017

Published 5 November 2017

\section{Keywords:}

Electrolysis

Nickel oxide

Water oxidation

Molecular precursor

Water splitting

\begin{abstract}
A B S T R A C T
In this study, we fabricated a $\mathrm{NiO}_{x}$ film by electrodeposition of an ethanediamine nickel complex precursor $(\mathrm{pH}=11)$ on a fluorine-doped tin oxide substrate. The resulting film is robust and exhibits high catalytic activity for electrochemical water oxidation. Water oxidation is initiated with an overpotential of $375 \mathrm{mV}\left(1 \mathrm{~mA} / \mathrm{cm}^{2}\right)$ and a steady current density of $8.5 \mathrm{~mA} / \mathrm{cm}^{2}$ is maintained for at least $10 \mathrm{~h}$ at $1.3 \mathrm{~V}$ versus the normal hydrogen electrode. Kinetic analysis reveals that there is a $2 \mathrm{e}^{-} / 3 \mathrm{H}^{+}$pre-equilibrium process before the chemical rate-determining step. The low-cost preparation, robustness, and longevity make this catalyst competitive for applications in solar energy conversion and storage.
\end{abstract}

(C) 2017, Dalian Institute of Chemical Physics, Chinese Academy of Sciences. Published by Elsevier B.V. All rights reserved.

\section{Introduction}

The massive consumption of fossil fuel is creating worldwide interest in searching for renewable energy sources [1,2]. Splitting water into oxygen and hydrogen by sunlight is a promising approach to achieve this goal $[3,4]$. However, water oxidation involves the release of $4 \mathrm{e}^{-}$and $4 \mathrm{H}^{+}$, and it requires a high thermodynamic overpotential $\left(2 \mathrm{H}_{2} \mathrm{O} \rightarrow \mathrm{O}_{2}+4 \mathrm{H}^{+}+4 \mathrm{e}^{-}\right.$, $1.23 \mathrm{~V}$ vs. the normal hydrogen electrode (NHE) at $\mathrm{pH}=0$ ) [5]. To efficiently drive this reaction, water oxidation catalysts (WOCs) with low overpotentials are crucial. Inspired by nature, great progress has been made in developing WOCs based on transition metals [6-14]. Although the activities of WOCs based on noble metals, such as ruthenium and iridium, are impres- sive, their practical application is hampered by their scarcity and high cost. Consequently, development of efficient WOCs based on earth-abundant elements is urgently required in the field of solar energy conversion.

Great effort has been made to develop WOCs derived from first row transition metals. In 2008, Nocera and co-workers reported that electrodeposition of cobalt phosphate (Co-Pi) on conductive substrates gave highly efficient electrocatalysts for water oxidation [15]. This method has been extended to other metals, such as iron and nickel [16-23]. For example, electrochemical deposition of an oxide film from molecular complexes is a promising approach to fabricate active Ni-based WOCs $[17,24,25]$. Recently, Spiccia and co-workers reported a facile protocol for electrodeposition of a $\mathrm{NiO}_{x}$ film from a nickel

\footnotetext{
*Corresponding author. Tel: +86-411-84986247; Fax: +86-411-84986245; E-mail: lifei@dlut.edu.cn

This work was supported by the National Basic Research Program of China (973 program, 2014CB239402), the National Natural Science Foundation of China (21476043), and the Swedish Energy Agency and K\&A Wallenberg Foundation

DOI: 10.1016/S1872-2067(17)62921-8 | http://www.sciencedirect.com/science/journal/18722067 | Chin. J. Catal., Vol. 38, No.11, November 2017
} 
amine complex in borate buffer [24]. The film exhibited a steady current density of $1.8 \mathrm{~mA} / \mathrm{cm}^{2}$ at $1.3 \mathrm{~V}$ vs. NHE in borate buffer. More recently, Allen and co-workers reported that the combination of $\mathrm{Ni}^{2+}$ and glycine could act as a precursor for an efficient nickel oxide electrocatalyst in phosphate buffer at $\mathrm{pH}=$ 11 [25]. However, the activity and durability of these catalysts needs to be improved. Here, inspired by this progress, we report a simple $\left[\mathrm{Ni}(\mathrm{en})_{3}\right] \mathrm{Cl}_{2}$ (en = ethanediamine) complex for facile electrodeposition of a nickel oxide film in phosphate buffer solution. The resulting film is inert to corrosion and exhibits superior catalytic activity to other molecular complex-derived catalysts. A current density of $8.5 \mathrm{~mA} / \mathrm{cm}^{2}$ is maintained for at least $10 \mathrm{~h}$ at a constant applied potential of $1.3 \mathrm{~V}$.

\section{Experimental}

\subsection{Materials and methods}

All of the chemicals were purchased from Aladdin Chemical Company and used without further purification. Deionized water $(18.2 \mathrm{M} \Omega / \mathrm{cm})$ obtained from a Milli-Q system (Millipore, Direct-Q 3 UV) was used throughout. The phosphate buffer solution $(0.25 \mathrm{~mol} / \mathrm{L}, \mathrm{pH}=11)$ was prepared by dissolving appropriate amounts of $\mathrm{Na}_{2} \mathrm{HPO}_{4} \cdot 12 \mathrm{H}_{2} \mathrm{O}$ and $\mathrm{Na}_{3} \mathrm{PO}_{4} \cdot 12 \mathrm{H}_{2} \mathrm{O}$ in deionized water. The $\left[\mathrm{Ni}(\mathrm{en})_{3}\right] \mathrm{Cl}_{2}$ complex was prepared according to a reported procedure [26]. The fluorine-doped tin oxide (FTO) substrates were purchased from Dalian Heptachroma SolarTech Co., Ltd. (thickness $\sim 2.2 \mathrm{~mm}$, transmittance $>90 \%$, resistance $\sim 8 \mathrm{~m} \Omega$ ). Scanning electron microscopy (SEM) and energy dispersive X-ray (EDX) analysis were performed with a Nova NanoSEM 450 scanning electron microscopy. The SEM images and EDX spectra were obtained with acceleration voltages of 3 and $20 \mathrm{kV}$, respectively. The catalyst content on the surface of the working electrode (FTO) was determined by inductively coupled plasma mass spectrometry (ICP-MS, (Optima 2000DV, America PerkinElmer Co.). The sample used for ICP-MS was prepared by depositing the $\mathrm{NiO}_{x}$ film on FTO with an applied bias of $1.2 \mathrm{~V}$ (vs. NHE). The sample was then gently rinsed with deionized water and dissolved in concentrated $\mathrm{HNO}_{3}$. The sample used for the measurement was diluted with water. X-ray photoelectron spectroscopy (XPS) was performed with a Thermo Scientific ESCALAB250 X-ray photoelectron spectrometer using $200 \mathrm{~W} K_{\alpha}$ radiation. The electrochemical measurements were recorded with a CHI 630D electrochemical potentiostat. The counter electrode was platinum wire. The reference electrode was an aqueous $\mathrm{Ag} / \mathrm{AgCl}(3 \mathrm{~mol} / \mathrm{L} \mathrm{NaCl})$ electrode. A glassy carbon electrode (diameter $3 \mathrm{~mm}$ ) or FTO film was used as the working electrode. All of the potentials were measured against a $\mathrm{Ag} / \mathrm{AgCl}$ reference and converted to the NHE by addition of $0.197 \mathrm{~V}$ to the measured potentials.

\subsection{Fabrication of the catalyst film}

The FTO substrates were ultrasonically cleaned in deionized water, ethanol, and acetone (30 min each), and then air-dried. The $\mathrm{NiO}_{x}$ films for the water oxidation experiments were de- posited by constant potential electrolysis (CPE) at $1.2 \mathrm{~V}$ (vs. $\mathrm{NHE})$ using a solution of $\left[\mathrm{Ni}(\mathrm{en})_{3}\right] \mathrm{Cl}_{2}(1 \mathrm{mmol} / \mathrm{L})$ in phosphate buffer solution $(0.25 \mathrm{~mol} / \mathrm{L})$. The films were then gently rinsed with deionized water and transferred to fresh $0.25 \mathrm{M}$ phosphate buffer solution for anodization (1.3 V vs. NHE bias was applied for about $1.5 \mathrm{~h}$ ).

\subsection{Current-potential measurements for the Tafel plot}

Current-potential data were obtained by performing controlled potential electrolysis in $0.25 \mathrm{~mol} / \mathrm{L}$ phosphate buffer solution at $\mathrm{pH}=11$ with a variety of applied potentials. A FTO electrode $\left(1 \mathrm{~cm}^{2}\right)$ coated with a $\mathrm{NiO}_{x}$ film (after anodization) was used as the working electrode. $\mathrm{Ag} / \mathrm{AgCl}$ and Pt wire were used as the reference and counter electrodes, respectively. Before data collection, the solution resistance (35 $\Omega$ ) was measured with a clean FTO working electrode using the potential loss for resistance (iR) test function to correct the Tafel plot for the iR drop. A catalyst film $\left(1 \mathrm{~cm}^{2}\right)$ was prepared by electrodeposition. Preconditioning the film by subjecting it to bulk electrolysis for several hours is necessary to obtain a reproducible Tafel slope value. A current density of $1.1 \mathrm{~mA} / \mathrm{cm}^{2}$ was applied for $\sim 6 \mathrm{~h}$ before collecting data for the Tafel plot. The steady-state currents were measured at a variety of applied potentials while the solution was stirred. The Tafel plot measurements were performed in $10 \mathrm{mV}$ steps between 0.88 and $0.97 \mathrm{~V}$. In a typical experiment, the current reached a steady state at a particular potential in 3 min and the current values were recorded after $5 \mathrm{~min}$. All of the measurements were performed twice. The obtained current values ranged from 22 $\mu \mathrm{A} / \mathrm{cm}^{2}$ to $1.84 \mathrm{~mA} / \mathrm{cm}^{2}$ in the applied potential range. The variation in the steady-state current of two runs at a particular potential was $<5 \%$. According to the current-potential data, the Tafel slope is $43 \mathrm{mV} /$ decade.

\subsection{Current-pH measurements}

The current-pH data were collected by performing electrolysis at a fixed applied potential of $0.91 \mathrm{~V}$ (vs. NHE) in 0.25 mol/L phosphate buffer solution with a variety of $\mathrm{pH}$ values. A FTO electrode $\left(1 \mathrm{~cm}^{2}\right)$ coated with a $\mathrm{NiO}_{x}$ film (after anodization) was used as the working electrode. $\mathrm{Ag} / \mathrm{AgCl}$ and Pt wire were used as the reference and counter electrodes, respectively. The solution had an initial $\mathrm{pH}$ value of 10.4 . The $\mathrm{pH}$ value gradually increased by adding small amounts of $\mathrm{NaOH}$ solution, and the current density was recorded after 5 min electrolysis at each $\mathrm{pH}$ value point. All of the data were collected with iR correction using a solution resistance value measured before each electrolysis. The $\mathrm{pH}$ values of the solution ranged from 10.4 to 11.6 and the measured currents ranged from $14 \mu \mathrm{A} / \mathrm{cm}^{2}$ to $1.56 \mathrm{~mA} / \mathrm{cm}^{2}$.

\subsection{Determination of the faradaic efficiency}

The faradaic efficiency measurements for oxygen evolution were performed in a gas-tight electrochemical cell. The cell was equipped with a FTO electrode coated with a $\mathrm{NiO}_{x}$ film. $\mathrm{Ag} / \mathrm{AgCl}$ 


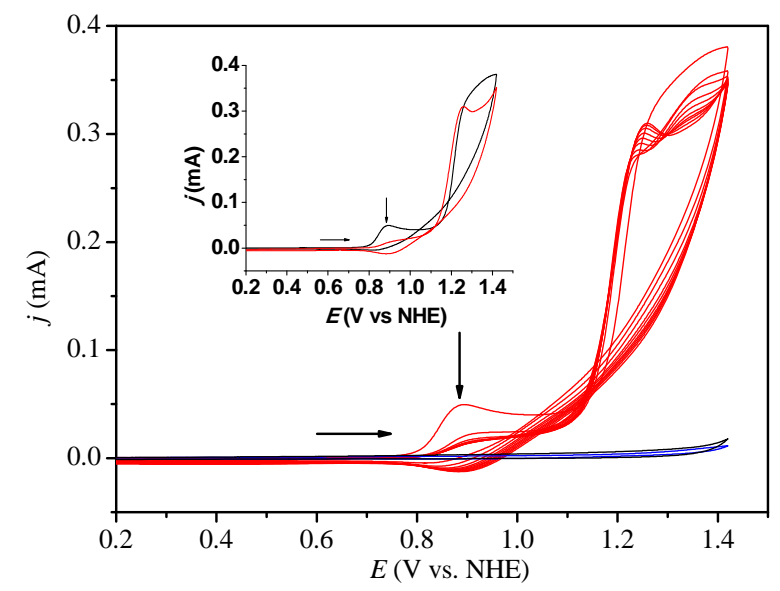

Fig. 1. Continuous CV scans of $1 \mathrm{mmol} / \mathrm{L}\left[\mathrm{Ni}(\mathrm{en})_{3}\right] \mathrm{Cl}_{2}$ in $0.25 \mathrm{~mol} / \mathrm{L}$ phosphate buffer $(\mathrm{pH}=11)$ recorded at a glassy carbon electrode with a scan rate of $100 \mathrm{mV} / \mathrm{s}$. The black trace is the scan of phosphate buffer solution containing $1 \mathrm{mmol} / \mathrm{L} \mathrm{Ni}^{2+}$. The blue trace is the scan of phosphate buffer without a nickel source. The insert shows the 1st (black) and 10th (red) CV scans.

and Pt wire were used as the reference and counter electrodes, respectively. Before the measurements, the solution was degassed by bubbling Ar for $2 \mathrm{~h}$ with vigorous stirring. Electrolysis was initiated at $1.3 \mathrm{~V}$ without iR correction. During bulk electrolysis, the amount of evolved oxygen in the headspace was determined by gas chromatography.

\section{Results and discussion}

Fig. 1 shows the cyclic voltammograms (CVs) of a glassy carbon electrode immersed in $0.25 \mathrm{~mol} / \mathrm{L}$ phosphate buffer solution $(\mathrm{pH}=11)$ containing $1 \mathrm{mmol} / \mathrm{L}\left[\mathrm{Ni}(\mathrm{en})_{3}\right] \mathrm{Cl}_{2}$. In the first anodic scan, an anodic peak occurs at $0.89 \mathrm{~V}$ (all of the reported potentials are versus NHE), which is followed by a steep catalytic current arising from water oxidation. In the cathodic return scan, there is a broad peak centered at $0.85 \mathrm{~V}$, which is attributed to reduction of the surface deposit formed in the initial anodic sweep. Repeated CV scans show the onset potential of water oxidation cathodically shifts while the cathodic peak anodically shifts. The catalytic current and cathodic peak increase in amplitude with scanning, suggesting growth of the material deposited on the surface. The intensity of the anodic peak decreases for the first three cycles and then remains stable. When $\mathrm{Ni}^{2+}$ is used instead of $\left[\mathrm{Ni}(\mathrm{en})_{3}\right] \mathrm{Cl}_{2}$, the $\mathrm{CV}$ trace is
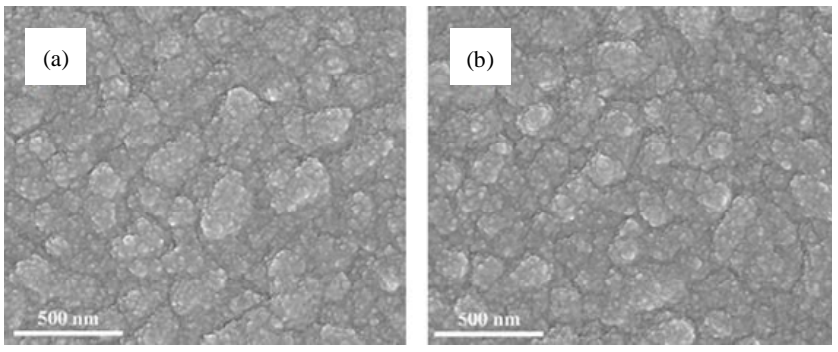

Fig. 2. SEM images of the $\mathrm{NiO}_{x}$ film before (a) and after (b) electrolysis.

relatively featureless and the current is below $10 \mu \mathrm{A}$, essentially overlapping the background. This is probably because of the low solubility of $\mathrm{Ni}^{2+}$ in the phosphate electrolyte solution inhibiting surface deposition.

Based on the CV experiments, a thin catalyst film was fabricated by anodic deposition on a FTO substrate at a constant potential of $1.2 \mathrm{~V}$ in $0.25 \mathrm{~mol} / \mathrm{L}$ phosphate buffer solution $(\mathrm{pH}=$ 11) containing $1 \mathrm{mmol} / \mathrm{L}\left[\mathrm{Ni}(\mathrm{en})_{3}\right](\mathrm{Cl})_{2}$. With $0.5 \mathrm{C} / \mathrm{cm}^{2}$ charge, about $0.84 \mu \mathrm{mol} / \mathrm{cm}^{2}$ of $\mathrm{Ni}$ was deposited on the surface of FTO, as determined by ICP-MS measurement. The as-prepared film was transferred into a fresh phosphate buffer solution. Upon applying a constant potential of $1.3 \mathrm{~V}$, the current density further increased until reaching a plateau. According to previous studies, this phenomenon might be associated with an anodization process $[17,27,28]$.

The SEM image in Fig. 2(a) show that the obtained film consists of compact packed nodules with sizes in the range 200-400 nm. XRD showed no characteristic diffraction peaks belonged to nickel species, indicating the amorphous character of the catalyst. EDX analysis was directly performed on the film after thorough rinsing with distilled water to remove any surface adsorbed components. The results showed that the film contained Ni, C, O, N, and P, as well as Sn and Si from the FTO substrate. The surface composition on the catalyst film was further investigated by XPS. The survey spectrum indicated the presence of Ni $2 p, \mathrm{P} 2 p$, and $\mathrm{O} 1 s$. In the Ni $2 p$ spectrum (Fig. $3(\mathrm{a}))$, the peaks at 855.4 and $873.2 \mathrm{eV}$ and the two satellite peaks at 860.7 and $879.1 \mathrm{eV}$ are ascribed to typical Ni(II) species. In the P $2 p$ spectrum (Fig. 3(b)), the characteristic peak of $\mathrm{P}$ at $132.7 \mathrm{eV}$ indicates the presence of a very small amount of $\mathrm{PO}_{4}{ }^{3-}$. In the $01 s$ spectrum (Fig. 3(c)), the peak at $531.2 \mathrm{eV}$ can be attributed to oxide and hydroxide on the surface of the film. According to the XPS results, the main component of the catalytic film is $\mathrm{NiO}_{x}$.
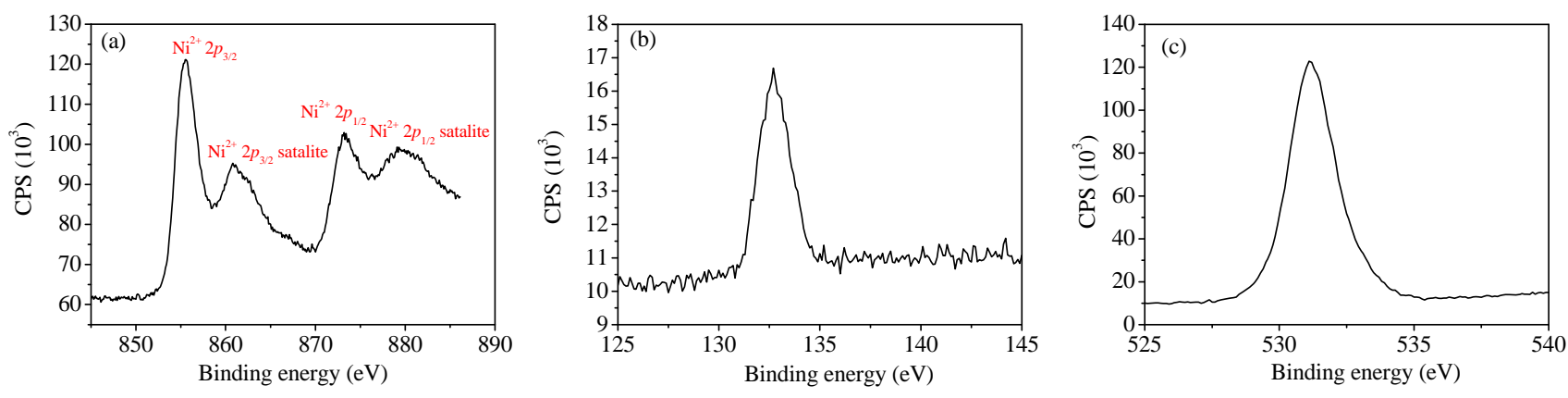

Fig. 3. Ni $2 p$ (a), P $2 p$ (b), and $01 s$ (c) XPS spectra of the electrodeposited film on the FTO electrode. 


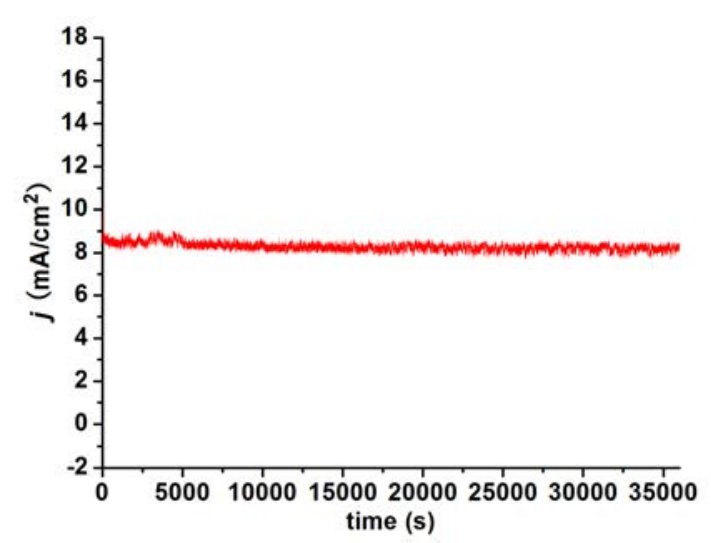

Fig. 4. Current density trace obtained by controlled potential electrolysis of the FTO electrode coated with a $\mathrm{NiO}_{x}$ film in stirred $0.25 \mathrm{~mol} / \mathrm{L}$ phosphate buffer solution $(\mathrm{pH}=11$ ) (reference electrode $\mathrm{Ag} / \mathrm{AgCl}$, counter electrode $\mathrm{Pt}$ wire, applied potential $1.3 \mathrm{~V}$, stirring rate 500 $\mathrm{r} / \mathrm{min}$, no iR correction).

Long-term electrolysis was performed at a constant potential of 1.3 V. Fig. 4 shows that a steady current of $8.5 \mathrm{~mA} / \mathrm{cm}^{2}$ is maintained for at least $10 \mathrm{~h}$, confirming the robustness of the catalyst film for water oxidation. The SEM image of the electrode shows no morphology change after electrolysis (Fig. 2(b)). During this process, the faradaic efficiency was deter- mined to be $98 \%$. The high activity and long-term stability show the potential of using $\mathrm{Ni}$ complexes as precursors for preparation of efficient WOCs.

The Tafel plot of $\log (j)$ against the overpotential $(\eta)$ has a slope of $46 \mathrm{mV} /$ decade for current densities ranging from 22 $\mu \mathrm{A} / \mathrm{cm}^{2}$ to $1.8 \mathrm{~mA} / \mathrm{cm}^{2}$ (Fig. 5(a)). It should be noted that preconditioning the film by bulk electrolysis for several hours is necessary to obtain a reproducible Tafel slope value. The slope of the Tafel plot of $\left[\mathrm{Ni}(\mathrm{en})_{3}\right]^{2+-}$-derived $\mathrm{NiO}_{x}$ is comparable with that of a glycine-nickel derived WOC [25] and significantly lower than those of other $\mathrm{Ni}$ oxides reported in the literature $[15,22,27,28]$, indicating favorable kinetics for water oxidation. According to the Tafel plot, water oxidation starts at $\eta=330$ $\mathrm{mV}$ (reaching a current density of $10^{-4} \mathrm{~A} / \mathrm{cm}^{2}$ ) and an overpotential of $375 \mathrm{mV}$ is required to reach a current density of 1 $\mathrm{mA} / \mathrm{cm}^{2}$. These values are much lower than those of the glycine-nickel WOC under the same working conditions [25]. The electrochemical properties of $\left[\mathrm{Ni}(\mathrm{en})_{3}\right]^{2+}$-derived $\mathrm{NiO}_{x}$ are summarized in Table 1, and they compare favorably with those of other $\mathrm{NiO}_{x}$ oxygen evolution reaction catalysts.

The pH-dependent $\mathrm{O}_{2}$ evolution activity of $\mathrm{NiO}_{x}$ was evaluated in Ni-free phosphate buffer solution. As shown in Fig. 5b, there is a linear relationship between $\log (j)$ and the $\mathrm{pH}$ at a bias of $0.91 \mathrm{~V}$, corresponding to a slope of 1.94 decade/ $\mathrm{pH}$. Using the equation $\left(\frac{\partial E}{\partial \mathrm{pH}}\right)_{j}=-\left(\frac{\partial \log j}{\partial \mathrm{pH}}\right)_{E}\left(\frac{\partial E}{\partial \log j}\right)_{\mathrm{pH}}$, the dependence of the overpotential on the $\mathrm{pH}$ is $-87 \mathrm{mV} / \mathrm{pH}$ unit, suggesting
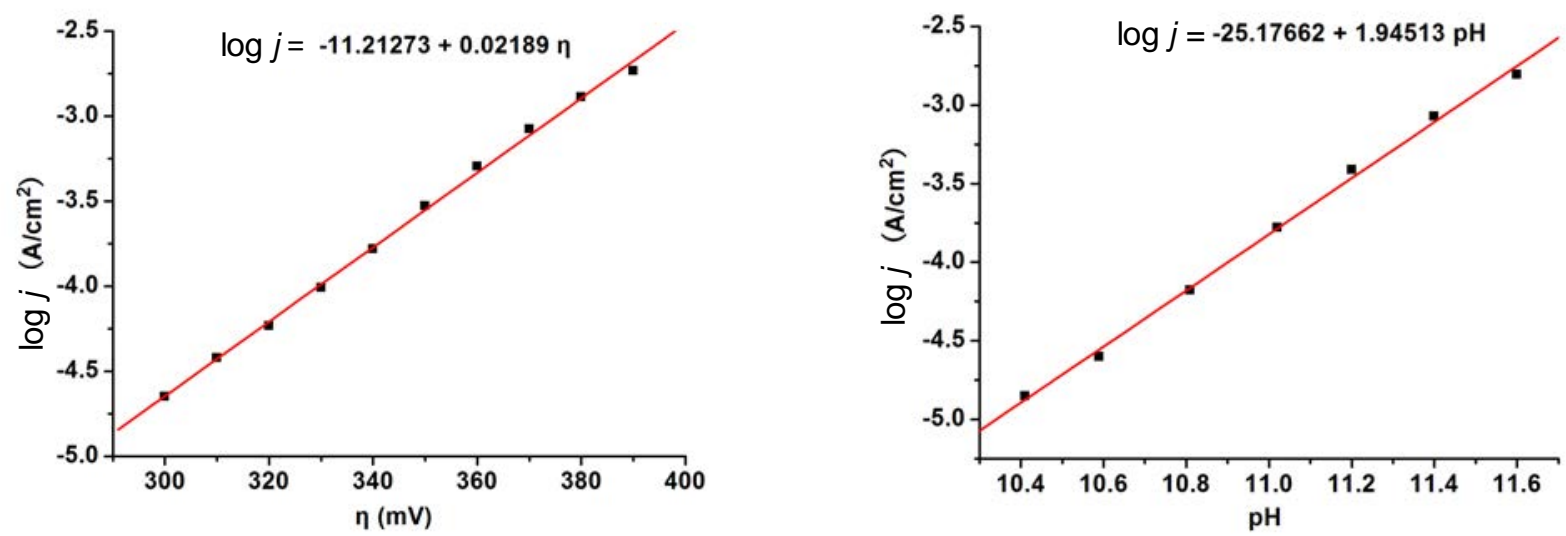

Fig. 5. (a) Tafel plot of the FTO electrode coated with a $\mathrm{NiO}_{x}$ film in $0.25 \mathrm{~mol} / \mathrm{L}$ phosphate buffer solution. $\eta=V_{\text {appl }}-\mathrm{iR}-E^{0}$, where $V_{\text {appl }}$ is the applied potential, $\mathrm{iR}$ is the potential loss for resistance, and $E^{0}=580 \mathrm{mV}$ is the thermodynamic potential for water oxidation at $\mathrm{pH}=11$. The slope of the plot is about $46 \mathrm{mV} /$ decade. (b) Relationship between the current density and the $\mathrm{pH}$ for the $\mathrm{NiO}_{x}$ film in $0.25 \mathrm{~mol} / \mathrm{L}$ phosphate buffer solution. The applied potential was $0.91 \mathrm{~V}$ with iR correction.

Table 1

Comparison of the electrochemical performance of $\mathrm{NiO}_{x}$ catalysts under near-neutral conditions.

\begin{tabular}{|c|c|c|c|c|c|c|}
\hline Nickel source & Electrolyte for $\mathrm{NiO}_{x}$ deposition & $\mathrm{CPE}^{\mathrm{a}}$ & $\begin{array}{l}\text { Overpotential at } 1 \\
\mathrm{~mA} / \mathrm{cm}^{2}\end{array}$ & $\begin{array}{c}\text { Tafel slope } \\
\text { (mV/decade) }\end{array}$ & $\begin{array}{c}\text { Faradaic efficiency } \\
(\%)\end{array}$ & Ref. \\
\hline$\overline{\mathrm{Ni}\left(\mathrm{NO}_{3}\right)_{2}}$ & $0.1 \mathrm{~mol} / \mathrm{L}$ borate buffer, $\mathrm{pH}=9.2$ & not given & 425 & 59 & 100 & [17] \\
\hline$\left[\mathrm{Ni}(\mathrm{en})_{3}\right] \mathrm{Cl}_{2}$ & $0.1 \mathrm{~mol} / \mathrm{L}$ borate buffer, $\mathrm{pH}=9.2$ & $1.8 \mathrm{~mA} / \mathrm{cm}^{2}$ at $1.33 \mathrm{~V} \mathrm{~b}$ & $552^{\mathrm{c}}$ & 105 & 93 & {$[24]$} \\
\hline $\mathrm{Ni}^{2+} /$ glycine & $0.25 \mathrm{~mol} / \mathrm{L}$ phosphate buffer, $\mathrm{pH}=11$ & $4 \mathrm{~mA} / \mathrm{cm}^{2}$ at $1.33 \mathrm{~V}$ & 475 & 40 & 60 & {$[25]$} \\
\hline$\left[\mathrm{Ni}(\mathrm{en})_{3}\right] \mathrm{Cl}_{2}$ & $0.25 \mathrm{~mol} / \mathrm{L}$ phosphate buffer, $\mathrm{pH}=11$ & $8.5 \mathrm{~mA} / \mathrm{cm}^{2}$ at $1.3 \mathrm{~V}$ & 375 & 46 & 98 & this work \\
\hline
\end{tabular}

a The electrolyte used for CPE was the same as that used for deposition of $\mathrm{NiO}_{x}$.

b Measured in $0.6 \mathrm{~mol} / \mathrm{L}$ borate buffer.

c Onset potential for oxygen evolution. 
that the loss of $1 \mathrm{e}^{-}$is accompanied by transfer of $\sim 1.5$ protons. For the nickel-glycine derived catalyst, the slope is $130 \mathrm{mV} / \mathrm{pH}$, which is consistent with a $2 \mathrm{e}^{-} / 1 \mathrm{H}^{+}$process, and a mechanism involving proton-coupled oxidation of $\mathrm{Ni}(\mathrm{II})$ to $\mathrm{Ni}(\mathrm{IV})$ was proposed [25]. Compared with the nickel-glycine catalyst, our catalyst film clearly has a different catalytic mechanism. In our system, a $2 \mathrm{e}^{-} / 3 \mathrm{H}^{+}$step may be operative. This is similar to a previously reported iridium oxide catalyst derived from dimerization of an $\operatorname{Ir}(\mathrm{IV})$ hydro-hydroxo species, which has a slope of $-89 \mathrm{mV} / \mathrm{pH}$ unit $[31,32]$.

\section{Conclusions}

In this study, we used a nickel amine complex as a precursor to prepare a $\mathrm{NiO}_{x}$ water oxidation catalyst. The molecular-derived $\mathrm{NiO}_{x}$ film exhibits favorable catalytic properties for electrocatalytic oxygen evolution at $\mathrm{pH}=11$. A low overpotential of $375 \mathrm{mV}$ with an activity of $1 \mathrm{~mA} / \mathrm{cm}^{2}$ is stable for at least $10 \mathrm{~h}$, and a current density of $8.5 \mathrm{~mA} / \mathrm{cm}^{2}$ can be achieved at a constant applied potential of $1.3 \mathrm{~V}$. The low Tafel slope of 46 $\mathrm{mV} /$ decade also indicates the favorable kinetic characteristics for electrocatalytic water oxidation. These results will be important for development of heterogeneous WOCs using inexpensive molecular precursors. The high activity and outstanding stability under benign conditions suggest more active WOCs may be accessible by varying the structure of the molecular precursor.

\section{Conflicts of interest}

There are no conflicts to declare.

\section{Acknowledgments}

The acknowledgements come at the end of an article after the conclusions and before the notes and references. This research was supported by the National Basic Research Program of China (973 program, 2014CB239402), the National Natural Science Foundation of China (21476043), the Swedish Energy Agency and K\&A Wallenberg Foundation.

\section{References}

[1] T. R. Cook, D. K. Dogutan, S. Y. Reece, Y. Surendranath, T. S. Teets, D. G. Nocera, Chem. Rev., 2010, 110, 6474-6502.

[2] N. S. Lewis, D. G. Nocera, Proc. Natl. Acad. Sci. USA, 2006, 103, 15729-15735.

[3] W. J. Youngblood, S. H. A. Lee, K. Maeda and T. E. Mallouk, Acc. Chem. Res., 2009, 42, 1966-1973.

[4] T. J. Meyer, Nature, 2008, 451, 778-779.

[5] J. Barber, Chem. Soc. Rev., 2009, 38,185-196.

[6] J. Barber, Inorg. Chem., 2008, 47, 1700-1710.

[7] K. N. Ferreira, T. M. Iverson, K. Maghlaoui, J. Barber, S. Iwata, Science, 2003, 303, 1831-1838.

[8] L. Duan, F. Bozoglian, S. Mandal, B. Stewart, T. Privalov, A. Llobet, L. Sun, Nat. Chem., 2012, 4, 418-423.

[9] E. Borgarello, J. Kiwi, E. Pelizzetti, M. Visca, M. Grätzel, J. Am. Chem. Soc., 1981, 103, 6324-6329.

[10] J. D. Blakemore, N. D. Schley, G. W. Olack, C. D. Incarvito, G. W. Brudvig, R. H. Crabtree, Chem. Sci., 2011, 2, 94-98.

[11] J. D. Blakemore, N. D. Schley, D. Balcells, J. F. Hull, G. W. Olack, C. D. Incarvito, O. Eisenstein, G. W. Brudvig, R. H. Crabtree, J. Am. Chem. Soc., 2010, 132, 16017-16029.

[12] N. D. Morris, T. E. Mallouk, J. Am. Chem. Soc., 2002, 124,

\section{Graphical Abstract}

Chin. J. Catal., 2017, 38: 1812-1817 doi: 10.1016/S1872-2067(17)62921-8

\section{Electrocatalytic water oxidation by a nickel oxide film derived from a molecular precursor}

Fei Li *, Hua Li, Yong Zhu, Jian Du, Yong Wang, Licheng Sun

Dalian University of Technology, China; KTH Royal Institute of Technology, Sweden

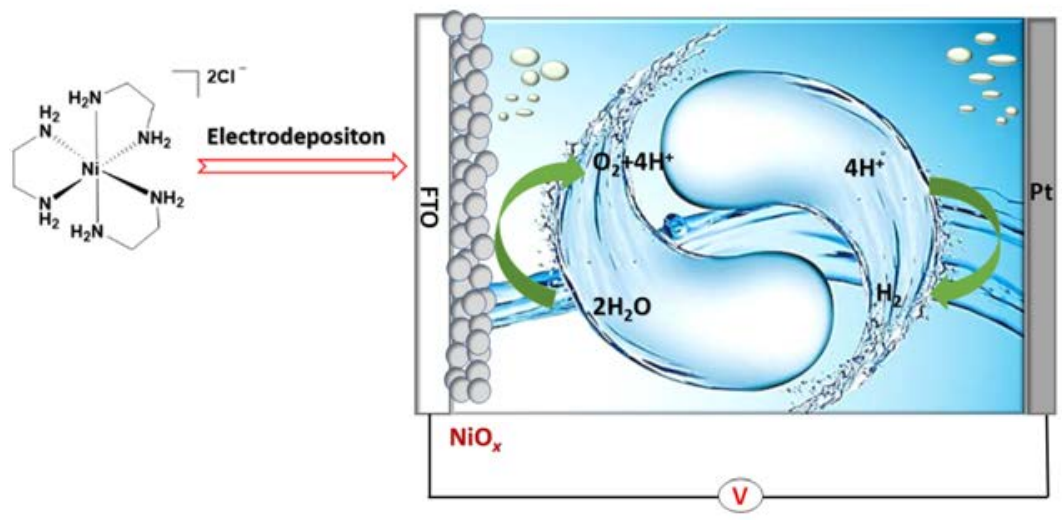

$\mathrm{A} \mathrm{NiO}_{x}$ film was prepared by electrodeposition of a nickel-based molecular precursor at $\mathrm{pH}=11$. The thin film exhibits high activity for electrochemical water oxidation. 


\section{4-11121}

[13] X. Du, J. Huang, Y. Feng, Y. Ding, Chin. J. Catal., 2016, 37, 123-134.

[14] Y. Huang, M. Zhang, P. Liu, F. Cheng, L. Wang, Chin. J. Catal., 2016, 37, 1249-1256.

[15] M. W. Kanan, D. G. Nocera, Science, 2008, 321, 1072-1075.

[16] Y. Surendranath, M. Dincă, D. G. Nocera, J. Am. Chem. Soc., 2009, 131, 2615-2620.

[17] M. Dincă, Y. Surendranath, D. G. Nocera, Proc. Natl. Acad. Sci. USA, 2010, 107, 10337-10341

[18] F. Zhou, A. lzgorodin, R. K. Hocking, L. Spiccia, D. R. Macfarlane, Adv. Energy Mater., 2012, 2, 1013-1021.

[19] M. Huynh, D. K. Bediako, D. G. Nocera, J. Am. Chem. Soc., 2014, 136, 6002-6010.

[20] F. S. Yu, F. Li, B. B. Zhang, H. Li, L. C. Sun, ACS Catal., 2015, 5, 627-630.

[21] J. L. Du, Z. F. Chen, S. R. Ye, B. J. Wiley, T. J. Meyer, Angew. Chem. Int. Ed., 2015, 54, 2073-2078.

[22] Y. Z. Wu, M. X. Chen, Y. Z. Han, H. X. Luo, X. J. Su, M. T. Zhang, X. H. Lin, J. L. Sun, L. Wang, L. Deng, W. Zhang, R. Cao, Angew. Chem. Int. Ed., 2015, 54, 4870-4875.
[23] W. D. Chemelewski, H. C. Lee, J. F. Lin, A. J. Bard, C. B. Mullins, J. Am. Chem. Soc. 2014, 136, 2843-2850.

[24] A. Singh, S. L. Y. Chang, R. K. Hocking, U. Bach, L. Spiccia, Energy Environ. Sci., 2013, 6, 579-586.

[25] D. Wang, G. Ghirlanda, J. P. Allen, J. Am. Chem. Soc., 2014, 136, 10198-10201.

[26] H. F. Crouse, J. Potoma, F. Neirabi, D. L. Snyder, B. S. Chohan, S. Basu, Dalton Trans., 2012, 41, 2720-2731.

[27] D. K. Bediako, B. Lassalle-Kaiser, Y. Surendranath, J. Yano, V. K. Yachandra, D. G. Nocera, J. Am. Chem. Soc. 2012, 134, 6801-6809.

[28] D. K. Bediako, Y. Surendranath, D. G. Nocera, J. Am. Chem. Soc. 2013, 135, 3662-3674.

[29] M. R. Gennerode Chialvo, A. C. Chialvo, Electrochim. Acta, 1988, 33, 825-830.

[30] X. Y. Wang, H. A. Luo, H. P. Yang, P. J. Sebastian, S. A. Gamboa, Int. J. Hydrogen Energy, 2004, 29, 967-972.

[31] L. D. Burke, D. P. Whelan, J. Electroanal. Chem. Interfacial Electrochem., 1984, 162, 121-141.

[32] L. D. Burke, D. P. Whelan, J. Electroanal. Chem. Interfacial Electrochem., 1981, 124, 333-337.

\title{
分子前驱体衍生的氧化镍电极催化水氧化性能研究
}

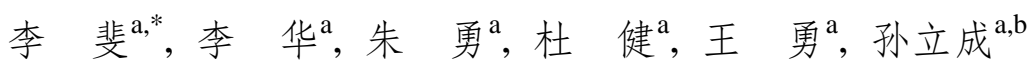 \\ ${ }^{\mathrm{a}}$ 大连理工大学精细化工国家重点实验室, 辽宁大连 116024 \\ 瑞典皇家工学院化学系, 斯德哥尔摩 10044 , 瑞典
}

摘要: 太阳能分解水制氢是解决当前能源和环境危机的潜在手段之一. 其中由于水氧化半反应涉及 4 个电子和 4 个质子的 转移, 因此是全分解水反应的瓶颈所在. 为了发展高效的水氧化催化剂, 降低水氧化过电位, 人们付出了巨大的努力. 目前 活性最高的水氧化催化剂都是基于钓和铱的贵金属催化剂, 高昂的成本阻碍了这些催化剂的规模化应用, 因此人们尝试利 用各种方法制备基于廉价金属的水氧化催化剂. 2008年, Nocera课题组利用电沉积法从磷酸溶液中得到了高活性氧化钴催 化剂, 之后该法逐渐得到推广. 最近, Spiccia和Allen课题组利用分子前驱体通过电沉积法制备了氧化镍催化剂, 但其催化 活性和稳定性有待进一步提高. 本文将一个简单的镍配合物 $\left[\mathrm{Ni}(\mathrm{en})_{3}\right] \mathrm{Cl}_{2}$ (en $=1,2$-乙二胺) 作为前驱体溶解到磷酸缓冲溶 液中, 在FTO基底上电沉积得到具有高催化活性的氧化镍水氧化催化剂.

在 $\mathrm{pH}=11$ 的磷酸缓冲溶液中, 由分子前驱体沉积所得到的 $\mathrm{NiO}_{x}$ 的催化电流达到 $1 \mathrm{~mA} / \mathrm{cm}^{2}$ 时的过电位为 $375 \mathrm{mV}$, 且可 稳定工作 $10 \mathrm{~h}$ 以上. 其催化过程中的Tafel斜率为 $46 \mathrm{mV} / \mathrm{decade}$, 表现出优异的动力学特性. 该电极和之前文献中催化活性 最高的从分子前驱体衍生得到的 $\mathrm{NiO}_{x}$ 相比展现出较大的优势. 比如在 $1.3 \mathrm{~V}$ (相对于 $\mathrm{NHE}$ )电压下, $\left[\mathrm{Ni}(\mathrm{en})_{3}\right] \mathrm{Cl}_{2}$ 衍生的 $\mathrm{NiO}_{x}$ 催 化电流密度可以达到 $8.5 \mathrm{~mA} / \mathrm{cm}^{2}$, 法拉第效率为 $98 \%$. 而 $\mathrm{Ni}$-氨基乙酸衍生的 $\mathrm{NiO}_{x}$ 在相同条件下催化电流密度为 $4 \mathrm{~mA} / \mathrm{cm}^{2}$, 法拉第效率仅为 $60 \%$. 该工作充分证明以分子配合物作为前驱体是制备高效高稳定性多相水氧化催化剂的简便途径. 有 机配体和金属螯合的分子前驱体在结构上具有灵活可调的特性, 从而有助于构建活性和效率更高的催化体系.

关键词: 电催化; 氧化镍; 水氧化; 分子前驱体; 分解水

收稿日期: 2017-08-30. 接受日期: 2017-09-25. 出版日期: 2017-11-05.

*通讯联系人. 电话: (0411)84986247; 传真: (0411)84986245; 电子信箱: lifei@dlut.edu.cn

基金来源：国家重点基础研究发展计划(973计划, 2014CB239402); 国家自然科学基金(21476043).

本文的电子版全文由Elsevier出版社在ScienceDirect上出版(http://www.sciencedirect.com/science/journal/18722067). 